ошейник употребляется в значении "воротник" в силу того, что мужчины носят рубашку навыпуск, однако верхняя пуговица обязательно должна всегда оставаться застегнутой. Это вызывает ассоциацию с тугим ошейником.

Таким образом, в пределах группы представлены социальные (5), геоморфные (1) и предметные (4) метафоры.

Всего было выявлено 28 метафорических номинаций: предметные (13), социальные (7), биоморфные (6), геоморфные (1) и цветовые (1). В них отражаются результаты познания мира, которые предстают яркими россыпями в повседневной речи носителей говора. Исследование показало, что для создания метафор активнее всего используется предметная сфера.

Некоторые номинации в их прямом значении употреблялись не столь часто. Но, благодаря метафорическому переносу, они вошли в активный словарь диалектоносителей, например: бедуин, кабардинка.

Метафорические номинации в говоре схожи с красками, благодаря которым художник передает всю палитру окружающего мира.

1. Брысина Е.В. Диалект через призму лингвокультурологии. // Вестник Волгоградского государственного университета. Серия 2. Языкознание, 2012, №2 (16), с. 51-56.

2. Гейдарова Э.А. Языковой портрет русского островного говора Азербайджана. Москва: Университетская книга, 2017, 303 с.

3. Гейдарова Э.А. Лексическая система русского островного говора Азербайджана. Баку: AVROPA, 2015, 178 c.

4. Гейдарова Э.А. Особенности выражения категории рода в русском островном говоре Азербайджана. // Sciences of Europe. Praha, Czech Republic, 2021, № 67, c. 20-25.

5. Гулиева Л.Г., Гейдарова Э.А. Лексикон русского островного говора Азер-байджана. Баку: Авропа, 2014, 498 c.

6. Гольдин В.Е. Теоретические проблемы коммуникативной диалектологии. Автореферат диссертации доктора филологических наук. Саратов, 1997, 33 с.

7. Удалых Г.Д. Языковая картина мира молокан-старообрядцев Азербайджана. // Русский язык и литература в Азербайджане. Баку: БСУ, 2015, № 4, с. 4-9.

8. Толстой Н.И. Язык и народная духовная культура. Очерки по славянской мифологии и этнолингвистике. М.: Языки славянской культуры, 1995, 483 с.

\title{
Демидова М.М. \\ К проблеме передачи категории диминутивности при переводе с русского на английский язык
}

Брянский государственный технический университет

(Россия, Брянск)

doi: 10.18411/lj-05-2021-269

\section{Аннотация}

Статья посвящена вопросам перевода русской субстантивной лексики с уменьшительно-ласкательными суффиксами на английский язык. Исследование проводилось на богатом материале художественного произведения Л. Улицкой. В статье рассматривается понятие категории диминутивности в русском и английском языках, анализируются способы передачи суффиксов на английский язык.

Ключевые слова: диминутивность, перевод, уменьшительно-ласкательные суффиксы, существительные, русский язык, английский язык.

\section{Abstract}

The article is devoted to the translation of Russian substantive lexis with diminutive suffixes into English. The research was carried out on the rich material of L. Ulitskaya's 
novel. The article considers the concept of the category of diminutivity in the Russian and English languages, analyzes the ways of transferring suffixes into English.

Keywords: diminutivity, translation, diminutive suffixes, nouns, the russian language, the english language.

Категория диминутивности является характерной чертой русской разговорной речи. По мнению многих лингвистов, диминутивность присуща русскому языку в большей степени, чем многим другим современным языкам. «Русский язык исключительно богат уменьшительными формами, кажется, что они встречаются в речи на каждом шагу» [1]. Наиболее продуктивны морфологические средства выражения диминутивности. По некоторым подсчетам в русском языке 22 суффикса, которые в той или иной степени передают указанное значение. Самые распространённые из них: ик-/-ек-, -иц-/-ец, -очк-/-ечк-, -оньк-/-еньк-, -урк-, -ушк-(юшк-), -инк-, -ышк- (-ишк-). В разное время изучением данного вопроса занимались Н.А. Петровский, А.В. Суперанская, Д.И. Ермолович, А. Вежбицкая и другие.

Английский, как язык аналитического строя, не обладает таким обширным спектром аффиксов, как русский, однако небольшой набор уменьшительноласкательных суффиксов присутствует: -let, -ie/y, -ette, -kin, -ule, -ock, -ling. Следует отметить, что уменьшительные суффиксы в британском варианте английского языка употребляются нечасто. Активное выражение эта категория получила в именах собственных: Annie, Kitty, Willy, Jimmy. Категория диминутивности в английском языке не могла остаться без внимания русских лингвистов. Так, Гальперин И.Р., Черкасская Е.Б. и Иванова И.П. тщательно изучали данное явление с середины 20 века.

В нашей статье нам бы хотелось рассмотреть данную категорию с точки зрения теории перевода. Цель исследования - выявить способы передачи уменьшительноласкательного значения средствами английского языка. Важно отметить, что уменьшительные суффиксы - не просто словообразовательные аффиксы, они значимы, т.е. придают существительному дополнительный оттенок значения, который важно отразить в переводе.

В качестве материала для анализа нами было выбрано художественное произведение Л. Улицкой «Даниэль Штайн, переводчик» и его англоязычная версия. Литературный текст сам по себе представляет трудную задачу для переводчика, а перевод с русского на английский в особенности ввиду разносистемности языков. В тексте художественного произведения важно отразить все нюансы, а значит постараться передать даже минимальные оттенки значения. Из текста романа методом сплошной выборки нами было отобрано 30 субстантивных лексических единиц с уменьшительно-ласкательными суффиксами. В ходе сравнительно-сопоставительного анализа нам удалось установить, что в английском языке они могут быть интерпретированы 5 способами.

1. Нулевой перевод.

Она обняла меня лёгкими ручками [6]... - She gave me a little hug [9]...

Как мы видим, в переводной версии анализируемое существительное не используется. Однако при помощи правильно подобранной конструкции и уточняющего определения little переводчику удалось передать смысл предложения с большой степенью достоверности. «Опущению подвергаются, как правило, те детали, которые, по мнению автора перевода, являются не существенными или даже избыточными в текущий момент повествования» [2].

2. Нейтрализация диминутивности.

В данном случае, под нейтрализацией мы понимаем опущение добавочных смысловых оттенков, выраженных суффиксами в русском языке. Мы разделили примеры на группы в зависимости от того, какой компонент значения опущен. С точки зрения передачи лексической единицы в целом, можно говорить об относительной 
эквивалентности, поскольку во всех примерах используются сложившиеся соответствия.

В первой группе примеров суффиксы подчеркивают размер указанных предметов, т.е. указывают на тот факт, что они маленькие. В переводной версии это никак не репрезентируется.

Мебель не гарнитурная, а явно собранная поштучно, и на каком-то низком шкафчике [6]... - The furniture was not a suite but had clearly been assembled piece by piece, and on a kind of low cupboard [9]...

...В городке было ужасное истребление евреев [6]... - ... There had been a terrible slaughter of Jews in the town[9]...

Здесь никаких ручек-ножек нет, а висят картинки детей [6]... - There were по arms or legs here [9]...

Дядя прислал фотографию домика в саду [6] ... - His uncle had sent a photograph of the house and garden [9]...

Следует отметить, что данные компоненты значений не являются первостепенно важными в контексте абзаца, главы и тем более произведения в целом, поэтому могут быть опущены без значимых семантических потерь, однако тон и стиль изложения утрачиваются.

Та комнатка была маленькой [6] ... - The room had been small [9]...

Мы живём в Кфар Сабе, у нас крохотная квартирка [6]... - We live in Kfar Saba in a tiny flat [9]...

В вышеприведенных иллюстрациях используется двойное преуменьшение: уменьшительный суффикс и определение с аналогичным значением. Такое явление характерно для русского языка, но не свойственно английскому. Как видим, в переводе исходное значение сохраняется неизменным за счет характеристик, выраженных прилагательными. Таким образом, здесь можно говорить о верном переводческом решении.

Вторая группа состоит из иллюстраций, в которых при переводе опускается оценочный компонент значения: ласковое отношение говорящего, тем самым придавая переводу более формальный и сухой тон.

Эти крестьянские лошадки [6] ... - They were peasants' horses [9]...

...Вот такую женщину, - хорошо бы в матери, в тётушки, в бабушки [6]. She would have been the perfect mother, aunt or grandmother [9].

Целую тебя, дорогой сыночек [6]. - All ту love, dear son [9].

Целую тебя, Мишенька, крестничек мой дорогой [6] . - I kiss уоu, Misha, my dear grandson [9].

Два последних примера представляют собой заключительную строчку личного письма, следовательно, каждое слово наполнено любовью и привязанностью. Несмотря на отсутствие ласкательного суффикса, переводной вариант полностью передает те теплые эмоции, которые выражает героиня, так как в английском тоже используются слова с эмоциональной окраской, и словосочетание мой дорогой воспроизводится дословно.

Добавила то, чего не знала и что рассказал мне Нафтали, весёльй старичок из Израиля [6] ... - I did not know but have been told by Naphtali, a cheery old man from Israel [9] ...

Такая старушка в платочке, которая еду крестила в шаббат [6]. - She was the old lady in a shawl [9] ...

Здесь вместо аналогичного существительного в английском языке используется именное словосочетание. Следовательно, можно констатировать отсутствие подобной лексической единицы, а значит сохранить ласкательный окрас вдвойне сложно. 
Нижеследующий пример мы выделили в отдельную группу, поскольку с нашей точки зрения, в данном случае суффикс передает два компонента: нежное отношение говорящего и размер, и оба они опущены в переводе.

Он ручки раскинул и бросился целоваться [6]. - Hе opened his arms and rushed to kiss me [9].

3. Компенсация за счет лексических средств, т.е. передача диминутивного значения посредством вставок, как правило, - это размерные или оценочные прилагательные.

В первой группе относительная эквивалентность при переводе достигается за счет вставки сразу двух добавочных элементов.

И обращуается она ко мне «деточка» [6]. - She even called me "my dear child"

Он молчал, но время от времени клал мне руку на голову, гладил по волосам и вздыхал: доченька моя [6] ... - Put his hand on my head, stroked my hair, and sighed, "Мy dear daughter" [9] ...

Притяжательное местоимение ту в английском всегда придает фразе более мягкий, ласкательный тон, а определение dear, выраженное оценочным прилагательным, очень ярко репрезентирует отношение говорящего и его чувства, тем самым передавая значение, выраженное суффиксом в русском языке.

Во второй группе русское существительное переводится на английский язык при помощи именного словосочетания: прилагательное + существительное.

Церковка чудесная, маленькая, сложена из камня [6]... - The little church is wonderful, small, built of stone [9] ...

...Ведь стареи был похоронен в подвале её домишки [6]. - ...The elder was buried in the cellar of that little house [9].

Прилагательные характеризуют размер существительных.

...Комната размером с большой диван и кухонька [6]... - There was one room the size of a large divan and a small kitchen [9]...

Данный вариант перевода представляется нам спорным, поскольку существует устойчивое соответствие: кухонька - kitchenette. Как в русском, так и в английском вариантах, существительные содержат уменьшительно-ласкательные суффиксы с идентичными значениями. Однако автор перевода предпочел воспользоваться вставкой.

...А в коние ХІХ века представляла собой небольшую арабскую деревушку [6]. By the end of the $19^{\text {th }}$ century it was a modest Arab village [9].

Примечательно, что автор переводной версии использует различные прилагательные: small, little, modest. Однако все они тем или иным образом указывают на размер, так modest - «not very big or expensive» [7]. Таким образом, в английском варианте получилось словосочетание с двумя определениями. уои [9].

A как мой братик в тебя был влюблён [6]? - And my little brother was in love with

Здесь, как нам кажется, помимо размерного компонента значения, который репрезентирован в английском языке при помощи дополнительной лексической единицы, важно и ласковое отношение говорящего. Тем не менее, оно не получило своего отражения в переводе.

4. Приближенный перевод - это перевод лексической единицы ИЯ при помощи единицы ПЯ с относительно аналогичным значением [3].

На самом деле все организовал один еврей, молодой парнишка [6]... - In reality everything was being organized by a young chap [9]...

Русское существительное парнишка имеет несколько подобных единиц в английском языке: guy, lad, fellow, chap. Все они отличаются мельчайшими оттенками значения. Употребление существительно парнишка в данном контексте подчеркивает 
возраст героя и передает трепетное, родительское отношение говорящего. Возраст героя дополнительно репрезентирован эквивалентными прилагательными в русском и английском языках. В толковом словаре находим: «chap - a man you know and like» [7]. Таким образом, ласкательный компонент заложен в основное значение, следовательно, можно говорить о некоем соответствии.

Mы подружились с пареньком [6]... - The boy and I became friends [9].

Форма паренек очень близка семантически форме парнишка, хотя даже еще более мягкая. «Boy - male child or young man» [7]. Так, характеристика возраста включена в английское понятие, а вот эмоциональная окраска полностью отсутствует.

... Возле речушек, которые попадались по пути, стояли очереди на водопой [6]. - People were queueing to water their horses at any streams [9]...

Английское stream - «a small, narrow river» [7], аналогичное понятие в русском выражается не специальным термином, а уменьшительно-ласкательной формой существительного речка, т.е. в данном предложении можно говорить о практически эквивалентном соответствии и о верном переводческом решении.

Я посылаю тебе фотографию Анечки, чтобы твои дети знали, какая у них есть сестричка в Москве [6]. - Your children should know what their cousin in Moscow looks like [9]...

В русском языке не существует однословного номинанта для понятия двоюродная сестра или двоюродный брат. Степень родства очень часто не уточняется. В нашем случае, из контекста понятно, что речь идет о двоюродной сестре, следовательно, вполне логично при переводе используется соответствующий английский термин. Однако дополнительные, эмотивные оттенки не репрезентируются.

Знаешь ли ты, что у него появилась подружка, от которой он в большом восторге [6]? - Did you know he has a girlfriend he is completely crazy about [9].

В этой паре также можно отметить очень высокую степень эквивалентности, поскольку и подружка и girlfriend, это кто-то, к кому испытывают теплые чувства, а значит набор семем почти одинаковый.

5. Контекстуальный перевод - это нерегулярное соответствие, которое возникает только в конкретном предложении и определяется контекстом.

Наконеи мостик кинули, и пошёл народ - туристы, конечно [6] ... - Finally they lowered the gangway [9] ...

Gangway - «a movable bridge linking a ship to the shore» [6], т.е. трап. В данном контексте подобная замена вполне объяснима, поскольку мостик используется как общий термин, а в английской версии имеет место конкретизация, дополнительный оттенок маленький утрачивается.

Итак, мы рассмотрели 30 иллюстраций и выявили 5 способов перевода. Тем не менее, диминутивность в той или иной степени сохраняется лишь в $36 \%$ случаев. При нулевом переводе, нейтрализации и контекстуальном соответствии диминутивность полностью утрачивается. Наиболее продуктивно диминутивные компоненты значения воспроизводятся при помощи компенсации и лишь частично при использовании аналогичных лексических единиц. Следует отметить, что на морфологическом уровне категория диминутивности в английской версии выражения не получила, поскольку «носитель английского языка...не может даже отдаленно вообразить себе все то огромное суффиксальное богатство русского языка, которое предоставляет его носителям возможность выразить столь же огромное богатство тончайших нюансов любящей души» [5]. Подводя итог вышесказанному, можно с уверенностью утверждать, что передать все коннотации, выраженные в русском языке уменьшительно-ласкательными суффиксами, при переводе на английский язык чрезвычайно сложно. Вследствие чего, «в английской версии авторское повествование 
становится более плоским, не отражающим ту игру точками зрения, которая заложена в русском оригинале, а языковая личность повествователя проявляется менее ярко» [4] .

$$
* * *
$$

1. Вежбицкая А. Язык. Культура. Познание/ А. Вежбицкая. - М., 1996.

2. Демидова М.М. Особенности перевода герундия в художественном тексте // Вестник ТГПУ. Томск, 2018. Вып. 8 (197). С. 39-44.

3. Демидова М.М. Способы передачи безэквивалентной лексики при переводе художественного текста (на материале романа Jane Austen "Sense and Sensibility" и его русскоязычной версии) // Филоlogos. Елец, 2020. № 3 (46). С. 34-43.

4. Менькова Н.В. Русские диминутивы в английском переводе романа М.А. Булгакова «Мастер и Маргарита»/ Н.В. Менькова// Ярослав. вестник. - 2010. - №5. - С.174-179.

5. Тер-Минасова С.Г. Язык и межкультурная коммуникация/ С.Г. Тер-Минасова. - М., 2002.

6. Улицкая, Л. Даниэль Штайн, переводчик: Роман / Л. Улицкая - М.: Эксмо, 2008. -528 с.

7. The Cambridge English dictionary. URL: http: // www.dictionary.cambridge.org (дата обращения 23.02.2021).

8. Longman Dictionary of Contemporary English. 3d ed. - Harlow. - Longman, 2001. - 1800pp.

9. Ulitskaya, Ludmila. Daniel Stein, interpreter: a novel in documents / Ludmila Ulitskaya; tr. by Arch Tait. - New York: Overlook press, 2011. -408 pp.

\section{Клемпач О.А. \\ Лингвистический анализ идиолектов жителей юго-запада Брянской области}

Филиал Брянского государственного университета в г. Новозыбкове (Россия, Новозыгкков)

doi: 10.18411/lj-05-2021-270

\section{Аннотация}

В статье проанализированы речевые особенности жителей юго-западных районов Брянской области, непосредственно граничащей с двумя восточнославянскими республиками - Белоруссией и Украиной. Лингвистический анализ идиолектов показал, что их специфика может быть объяснена таким понятием, как межъязыковая интерференция восточнославянских языков.

Ключевые слова: идиолект, лингвоперсоносфера, юго-запад Брянской области, российско-белорусско-украинское пограничье.

\section{Abstract}

The article analyzes the speech features of residents of the southwestern regions of the Bryansk region, directly bordering the two East Slavic republics - Belarus and Ukraine. Linguistic analysis of idiolects showed that their specifics can be explained by such a concept as inter-language interference of East Slavic languages.

Keywords: idiolect, linguopersonosphere, south-west of the Bryansk region, RussianBelarusian-Ukrainian border.

Наибольший вклад в изучение проблемы индивидуального использования языка внесли А. М. Пешковский, В. В. Виноградов, А. А. Шахматов. Последний утверждал, что «реальное бытие имеет язык каждого индивидуума; язык села́, города, области оказывается известной фикцией, ибо он слагается из фактов языка, входящих в состав тех или иных территориальных или племенных единиц индивидуумов» [6, с. 59]. Е. В. Богданова указывает, что интенсивное и многоплановое исследование речи отдельных носителей языка привело к появлению новых терминологических единиц: речевой портрет, идиолект, языковая личность, идиостиль [1, с. 102]. Остановимся подробнее на термине идиолект.

Идиолект - это индивидуальный язык, совокупность формальных и стилистических особенностей речи. В отечественной лингвистике под идиолектом 